\title{
KINERJA SAHAM DURABLE GOODS DAN NONDURABLE GOODS MASA KRISIS FINANSIAL GLOBAL
}

\author{
Mohamad Samsul \\ mohamadsamsuldrmsi@gmail.com
}

Fakultas Ekonomi Universitas 17 Agustus 1945 Surabaya

\begin{abstract}
The purpose of this research is to analyze the stock performance of "the durable goods" and "the nondurable goods" during global financial crisis of 2008. The amount of sample used is about 298 kinds of stocks with the data of individual stock index and coupon rate of government bond. The stock performance used Sharpe's Model. The period of financial crisis divided into two periods: contraction period and recovery period. Hypothesis: (1) there are differences of stock performance between the durable goods and the nondurable goods during each of contraction period and recovery period; (2) there are differences of stock performance between recovery period and contraction period for each of durable goods and nondurable goods. The result of this research showed that: (1) the stock performance of durable goods is insignificantly different than nondurable goods neither for contraction nor recovery period; (2) the stock performance is significantly difference between contraction and recovery period for each of durable goods and nondurable goods. These result was consistant to prior research. Suggestion: the treatment policy of nondurable goods should be the same as durable goods during the contraction and recovery periods, when the global financial market shock occurred.
\end{abstract}

Keywords: durable goods, nondurable goods, stock performance, contraction, recovery.

\section{PENDAHULUAN}

Penelitian ini dimaksudkan untuk menganalisis kinerja saham tercatat di Bursa Efek Indonesia dalam masa krisis ekonomi global sejak awal tahun 2008 yang berdampak di pasar modal Indonesia sejak awal tahun 2008 dan berakhir pada Maret 2010. Investor setiap saat selalu memperhatikan perkembangan ekonomi internasional dan pengaruhnya terhadap Pasar Modal nasional. Jika kecenderungan ekonomi internasional akan berpengaruh negatif terhadap perekonomian nasional, maka investor akan mempertimbangkan untuk keluar dari pasar modal sampai keadaan ekonomi pulih kembali. Jika perekonomian internasional akan berpengaruh positif terhadap perekonomin nasional, maka investor akan masuk ke pasar modal. Oleh karena itu, media 
komunikasi untuk mengetahui gerakan perubahan perekonomian dunia maupun domestik menjadi sarana penting bagi ivestor. Investor juga wajib memiliki data perdagangan saham harian, bulanan, tahunan dan tingkat bunga bebas risiko untuk kepentingan analisis.

Krisis finansial global datang dari Pasar Modal Amerika Serikat. Indikator adanya krisis tersebut mulai tampak pada pertengahan tahun 2007 pada saat jatuhnya produk subprime mortgage di pasar keuangan Amerika Serikat. Subprime mortgage adalah surat utang yang diterbitkan oleh perusahaan investasi ataupun perbankan yang dijamin oleh Aset Piutang. Subprime mortgage merupakan tindakan financial engineering berupa sekuritisasi aset perusahaan. Subprime mortgage tidak dijamin oleh pemerintah karena merupakan produk turunan (derivative product) tingkat tiga. Pemerintah hanya menjamin surat utang bernama "Mortgage Backed Securities" atau MBS, yang diterbitkan oleh perusahaan negara.

Malapetaka ekonomi yang terjadi di Amerika Serikat akan berdampak langsung kepada perekonomian negara-negara lain yang memiliki hubungan ekonomi internasional. Tingkat dampak yang dialami oleh tiap negara berbeda sesuai dengan tingkat hubungan ekspor/impor ataupun transaksi finansial lainnya. Makin tinggi tingkat nilai ekspor/impor dan transaksi finansial dengan Amerika Serikat, makin tinggi dampak yang akan dialami oleh negara bersangkutan. Bagi Indonesia, krisis finansial global tersebut relatif kecil pengaruhnya terhadap perekonomian Indonesia karena ekspor Indonesia ke Amerika Serikat hanya sekitar $16 \%$ dari total ekspor dan sedikit sekali perusahaan yang melakukan transaksi derivatif di Pasar Modal Amerika Serikat.

Dampak krisis global terhadap sektor riil relatif sangat kecil, hanya sekitar 15\%. Sektor riil hanya mengalami penurunan tingkat pertumbuhan ekonomi dari $6 \%$ menjadi $4,5 \%$. Selama krisis global berlangsung Indonesia masih tumbuh positif, seperti halnya China dan India. Namun demikian dampak terhadap sektor finansial sangat besar yaitu Index Harga Saham Gabungan jatuh sekitar 55\%. IHSG jatuh dari posisi 2.746 (akhir Desember 2007) ke posisi 1.242 (akhir Nopember 2008) atau berlangsung 11 bulan saja. Selanjutnya, penelitian ini ingin mengkaji dampak krisis finansial global terhadap investasi saham di Pasar Modal Indonesia. Investor selalu menjaga portofolio saham dari goncangan harga akibat siklus ekonomi yang mungkin terjadi. Investor akan berupaya memuat keseimbangan komposisi antara saham perusahaan yang menghasilkan "durable goods" (tahan lama) dan saham perusahaan yang menghasilkan "nondurable goods" (tidak tahan lama).

Dalam kondisi ekonomi normal, gejolak harga saham-saham "durable goods" naik turun lebih tinggi daripada gejolak harga saham "nondurable goods". Penelitian (Monacelli, 2008), menyatakan bahwa penurunan harga saham "durable goods" berbeda tidak 
signifikan dengan penurunan harga saham "nondurable goods". Apakah di Indonesia juga demikian?. Untuk menjawab pertanyaan itu penelitian ini dilakukan.

Berdasarkan uraian di atas maka ditarik rumusan masalah dalam penelitian ini adalah sebagai berikut:

1. Apakah reward to variability ratio atas saham durable goods lebih rendah daripada nondurable goods pada masa Kontraksi.?

2. Apakah reward to variability ratio atas saham durable goods lebih tinggi daripada nondurable goods pada masa Recovery.?

3 Apakah reward to variability ratio atas saham durable goods lebih tinggi pada masa recovery daripada masa Kontraksi.?

4. Apakah reward to variability ratio atas saham nondurable goods berbeda pada masa recovery daripada masa Kontraksi.?

Adapun tujuan dari penelitian ini adalah: (1). Untuk menganalisis perbedaan kinerja saham antara saham-saham kelompok durable goods dan nondurable goods, untuk masa kontraksi. (2). Untuk menganalisis perbedaan kinerja saham antara saham-saham kelompok durable goods dan nondurable goods, untuk masa recovery. (3). Untuk menganalisis perbedaan kinerja saham kelompok durable goods antara masa recovery dan masa kontraksi. (4). Untuk menganalisis perbedaan kinerja saham kelompok nondurable goods antara masa recovery dan masa kontraksi.

Manfaat yang diharapkan dari penelitian ini adalah: (1). Bagi masyarakat investor hasil penelitian ini sangat penting sebagai pelajaran untuk pengambilan keputusan memilih saham yang layak dibeli ataupun layak dijual pada masa Kontraksi dan masa recovery jika krisis finansial terjadi lagi pada masa mendatang. (2). Bagi dunia pendidikan, hasil penelitian ini akan meningkatkan kedekatan antara pendekatan teoritis dan pelaksanaan dunia praktis.

\section{TINJAUAN TEORETIS}

Perdagangan efek di bursa selalu bersifat internasional. Para pelaku bursa, baik investor maupun anggota bursa selalu orang domestik dan orang asing. Semua peraturan berkaitan dengan sistem keanggotaan, sistem perdagangan, sistem pencatatan, dan sistem pengawasan bersifat internasional. Pada saat ini perdagangan efek dapat dilaksanakan secara bersamaan waktu antara bursa efek antar negara. Di Amerika Serikat waktu pagi hari perdagangan dibuka dan di Singapura waktu malam hari, maka perdagangan efek dapat dilaksanakan antara investor Singapura dan investor Amerika Serikat pada saat yang sama. Saat ini banyak negara yang bursa efeknya beroperasi 24 jam, berkat kemajuan teknologi dan komunikasi. Dunia saat ini layaknya sudah tidak ada batas-batas negara secara fisik untuk transaksi finansial (borderless trading). Amerika Serikat 
sebagai negara adikuasa di bidang ekonomi akan memberi dampak yang besar kepada negara lain jika terjadi gejolak perekonomiannya. Besarnya dampak tersebut tergantung pada tingkat hubungan nilai ekonomi antar negara-negara tersebut dan Amerika Serikat.

Krisis finansial global 2008 berawal dari Amerika Serikat, mengantarkan Amerika Serikat ke depresi ekonomi lebih dari dua tahun. Banyak negara lain terkena dampaknya dan ikut mengalami kemunduran ekonomi dengan pertumbuhan ekonomi di bawah nol atau minus, kecuali beberapa negara yang masih positif pertumbuhannya misalnya; Cina, India dan Indonesia.

Walaupun dalam sektor riil dampak ekonomi terhadap Indonesia atas krisis finansial global tidak terlalu besar, tetapi dampak terhadap Pasar Modal Indoneisia telah menurunkan IHSG sebesar 55\% dan Index Bursa Singapura turun 40\% pada Nopember 2008, padahal dampak negatif di sektor riil Singapura jauh lebih besar daripada Indonesia.

Jenis saham apakah sebaiknya untuk investasi? Jawabannya tergantung pada estimasi hasil yang lebih menguntungkan (outperform) antar jenis saham. Hal ini berkaitan dengan bisnis cycle. Para ahli ekonomi membagi siklus bisnis menjadi 4 tahapan. Pertama, tahap ekonomi mengalami kemajuan pesat atau ekspansi (peak). Kedua, tahap ekonomi mengalami kemunduran atau resesi (kontraksi). Ketiga, tahap ekonomi mengalami kejatuhan jangka panjang atau depresi (trough). Keempat, tahap ekonomi mengalami pemulihan kembali atau recovery. Sebelum suatu siklus bisnis itu terjadi akan ada indikator awal yang mendahuluinya yang disebut leading indicator. Salah satu contoh leading indicator adalah index harga saham. Jika harga-harga saham mulai bergerak naik terus menerus dalam beberapa bulan, maka dapat diartikan kondisi ekonomi akan segera membaik. Berita kenaikan harga saham merupakan "a good news" dan akan mendorong investor untuk membeli saham-saham dari industri yang memproduksi barang-barang tahan lama. Sebaliknya, jika harga saham turun terus menerus dalam beberapa bulan sebagai tanda kondisi ekonomi akan menurun, maka investor akan menjual saham-saham dari industri yang memproduksi barang-barang tahan lama. Harga saham dari industri semacam ini sangat bergejolak naik dan turun secara tajam. Oleh karena itu disebut sebagai industri yang sangat dipengaruhi oleh siklus ekonomi.

Bodie et al. (2008) menyatakan; "as the economy passes through different stages of the business cycle, the relative performance of different industry group may be expected to vary. For example at a trough, just before the economy begins to recover from a recession, one would expect that cyclical industries, those with above-average sensitivity to the state of the economy, would to outperform other industries. Examples of cyclical industries are producers of durable goods such as automobiles or washing machines. Because purchases of these goods can be deferred during a recession, sales are particularly sensitive to macroeconomic conditions." 
Sebaliknya, ada jenis saham dari perusahaan yang memproduksi "produk tidak tahan lama" atau disebut nondurable goods yang gejolak harganya sedikit sensitif terhadap siklus bisnis. Harga produk relatif stabil dalam keadaan siklus bisnis apapun, sehingga harga saham perusahaan hanya sedikit terpengaruh oleh siklus bisnis. Perusahaan yang memproduksi nondurable goods ini disebut defensive industries. Perusahaan yang termasuk dalam kelompok defensive industries akan memiliki kinerja lebih baik daripada perusahaan kelompok lainnya ketika ekonomi memasuki tahapan pemulihan ekonomi.

Selanjutnya, Bodie et al. (2008) menyatakan tentang defensive industry sebagai berikut; "there are industries that produce goods for which sales and profits are lest sesintive to the state of the economy. Defensive industries include food producers and processors, pharmaceutical firm, and public utilities. These industries will outperform others when the economy enter a recession."

Untuk menjawab pertanyaan apakah selama krisis finansial berlangsung masih perlu berinvestasi pada saham ataukah sebaiknya keluar dari pasar modal?, maka dibutuhkan analisis berdasarkan data pengalaman krisis finansial global 2008. Jawaban atas pertanyaan ini penting untuk mengambil keputusan investasi di kemudian hari jika terjadi krisis ekonomi yang relatif sama. Untuk menjawab pertanyaan di atas perlu dilakukan analisis kinerja saham.

Saham yang layak dibeli atau diinvestasi adalah saham yang memiliki nilai masa datang lebih tinggi daripada harga pasar sekarang. Bodie et al (2002) menyatakan; "whenever the intrinsic value, or the investor's own estimate of what the stock is really worth, exceeds the market price, the stock is considered undervalued and a good investment." Saham yang "Layak Beli" atau "Layak Investasi" disebut sebagai undervalued stocks.

Definisi lain diberikan oleh Francis tentang istilah "Layak Beli" atau "Layak Investasi" dengan kata "Underpriced". Dikatakan underpriced jika expected return lebih tinggi daripada minimum rate of return (Francis 1991). Jadi, jika Bodie et al melihat undervalued stock dari sudut "harga atau nilai saham" sedangkan Francis melihat dari sudut "return saham." Kalau saham itu "Tidak Layak Beli" berarti "Layak Jual" disebut "Overvalued stocks".

Penelitian ini menggunakan istilah undervalued stocks seperti yang didefinisikan oleh Francis. Analisis yang menghasilkan undervalued stocks dan overvalued stocks merupakan evaluasi kinerja saham masa lalu. Evaluasi kinerja saham tidak lain dimaksudkan sebagai dasar untuk mengambil keputusan investasi jika estimasi kondisi ekonomi masa akan datang dianalisis relatif mendekati sama dengan masa lalu. Return saham adalah hasil investasi yang dinyatakan dalam persentase. Return saham diperoleh dari penghitungan perubahan indeks harga saham individu bulanan atau tahunan. Indeks Harga Saham Individu (IHSI) setiap hari diterbitkan oleh pihak bursa. Untuk pertama kali 
suatu perusahaan mencatatkan sahamnya di bursa pada Harga Perdana (harga yang tertera dalam prospektus) oleh bursa efek Harga Perdana tersebut diberi indeks dengan angka 100. Selanjutnya, setiap perubahan harga saham akan secara otomatis indeks saham individu berubah. Hal ini berarti di kemudian hari suatu IHSI lebih dari angka 100 yang menunjukkan perusahaan bertambah baik dan di bawah angka 100 yang menunjukkan perusahaan kurang baik. Untuk keperluan analisis jangka panjang, penggunaan IHSI untuk menghitung return saham sangat baik karena terbebas dari pengaruh tindakan corporate action perusahaan.

\section{Penelitian Terdahulu}

Penelitian mengenai kinerja mutual fund atau reksa dana pernah dilakukan oleh Treynor (1965), Sharpe (1966), Jensen (1968), dan Modigliani and Modigliani (1997). Reksa Dana adalah suatu portofolio efek, yaitu kombinasi saham, obligasi dan sertifikat perbankan. Dalam penilaian kinerja saham dibutuhkan 3 informasi mengenai; expected return, minimum return, dan risiko investasi.

Pertanyaan berikutnya adalah bagaimana menentukan expected return, minimum return, dan risiko? Cara yang paling obyektif adalah menggunakan data riil masa lalu. Expected return dihitung berdasarkan rata-rata return masa lalu. Demikian juga penghitungan minimum return. Untuk lebih detailnya, pengukuran undervalued stocks mengikuti model Sharpe.

Sharpe (1966) menyatakan;"the capital-market model described here deals with predictions of future performance. Since the predictions cannot obtained in any satisfactory manner, the model cannot be tested directly. Instead, ex post values must be used the average of return of a portfolio must be substituted for expected rate of return, and the actual standard deviation of its rate of return for its predicted risk".

Sharpe (1966) menghubungkan antara besarnya reward dan besarnya risiko. Perbandingan antara reward dan risiko diberi nama reward-to-variability ratio $(R / V)$. Selanjutnya Sharpe menyatakan: "the larger the ratio, the better the performance". Berikut ini formula: Model Sharpe, $R / V=\left(r_{p}-r_{f}\right) / \sigma_{p}$

Keterangan:

$R / V \quad=$ Reward to variability ratio Model Sharpe

$r_{p} \quad=$ Average annual return portofolio, capital gain dikurangi biaya jual/beli, dan biaya administrasi mutual funds (Sharpe, 1966).

$r_{f} \quad=$ Risk free tahunan

$\sigma_{p} \quad=$ Standar deviasi return portofolio sebagai tolok ukur risiko

Sharpe mengukur suatu kinerja investasi berupa reward to variability ratio. Reward adalah excess return, yaitu return dikurangi minimum return. Variability adalah standar deviasi return. Minimum return yang dimaksud Sharpe adalah risk free rate. 
Sharpe melakukan penelitian terhadap 34 mutual funds untuk masa 1954-1963, dengan tujuan untuk mengembangkan hasil penelitian Treynor berkaitan dengan model yang diusulkan lewat tes empiris untuk mengevaluasi kemampuan prediksi. Perbedaan penelitian Treynor dan Sharpe terletak pada tolok ukur risiko. Treynor (1965) menggunakan beta, sedangkan Sharpe menggunakan standar deviasi. Treynor menganggap fluktuasi pasar sangat berperan dalam mempengaruhi return, sedangkan Sharpe menekankan pada risiko total. Hasil penelitian menyatakan bahwa reward-tovariability ratio bervariasi antara 0,43 sampai 0,78 . Sebelas dari 34 perusahaan mutual funds yang diteliti atau 32\% menghasilkan return lebih baik daripada return DJIA, sementara return dari indeks DJIA sebesar 0,67. Selanjutnya, Sharpe menyatakan;" equally important, there is no assurance that past performance is the best predictor of future performance".

Penelitian ini tentang kinerja saham individu, oleh karena itu formula Sharpe tersebut harus diubah notasinya menjadi:

Model Sharpe, $R / V=\left(r_{i}-r_{f}\right) / \sigma_{i}$

Keterangan:

$\begin{array}{ll}R / V & =\text { Reward to variability ratio } \\ r_{i} & =\text { Average annual return } \\ r_{f} & =\text { Risk free tahunan } \\ \left(r_{i}-r_{f}\right) & =\text { Excess return } \\ \sigma_{i} & =\text { Standar deviasi return }\end{array}$

Capital gain dan transaction cost diabaikan karena nilainya relatif sangat kecil.

Model Jensen sedikit berbeda dengan Model Sharpe ataupun Model Treynor. Apabila Model Sharpe ataupun Model Treynor dapat menerima investasi asalkan expected return berada di atas risk free, maka model Jensen menerima dengan persyaratan. Model Jensen mensyaratkan bahwa pendapatan di atas risk free atau biasa disebut risk premium, atau excess return harus proporsional dengan tingkat risiko pasar atau biasa disebut beta ${ }_{l}$, atau beta $_{p}$. Beta ${ }_{i}$, adalah risiko fluktuasi saham, $i$, terhadap fluktuasi harga pasar. Beta ${ }_{p}$, adalah risiko fluktuasi suatu portofolio terhadap fluktuasi harga pasar. Jensen menentukan minimum required rate of return untuk dapat menerima suatu investasi. Jensen menggunakan formula Capital Asset Pricing Model (CAPM), yang ditulis oleh Sharpe (1964) dan Lintner (1965) untuk penghitungan minimum required rate of return. Seperti Treynor dan Sharpe, Jensen ingin mengajukan model prediksi kinerja mutual funds dengan menggunakan ukuran kinerja yang absolut, yaitu menggunakan data aktual masa lalu. Untuk maksud tersebut Jensen meneliti 115 open-end mutual funds selama periode 1945 sampai dengan 1964 atau 20 tahun.

Hasil penelitian Jensen (1968) menunjukkan bahwa 76 mutual fund menghasilkan alpha lebih kecil daripada nol $\left(\alpha_{\mathrm{j}}<0\right)$, sedangkan 39 mutual fund atau 34\% dari total menghasilkan alpha lebih besar daripada nol $\left(\alpha_{j}>0\right)$. Penelitian kinerja mutual fund yang 
dilakukan oleh Treynor (1965) dan Jensen (1968) dan dua penelitian tersebut menggunakan tolok ukur risiko investasi adalah "beta saham". Ukuran beta saham hanya cocok untuk analisis dalam kondisi ekonomi normal. Disamping itu ada penelitian lain yang menyatakan bahwa semua studi secara keilmuan tentang mutual funds menghasilkan kesimpulan yang sama.

Penelitian McDonald (1974) yang dikutip oleh Francis (1991) terhadap 123 mutual funds untuk data 120 bulan dengan risk free berdasar 30 hari bunga commercial paper, menyimpulkan bahwa kinerja mutual funds dengan Treynor's Model menghasilkan 67 dari 123 mutual funds atau sekitar 50\% mempunyai monthly average return di atas stock market average return. Apabila dianalisis dengan Sharpe's Model menghasilkan 39 dari 123 mutual funds atau sekitar 32\% mempunyai monthly average return di atas stock market average return. McDonald (1974) menyatakan;"thus, using a slightly different specification of the Sharpe and Treynor portfolio performance measures and a different sample did not yield any significantly different conclusions. The Treynor, Jensen, and Sharpe investment performance measures all tend to rank mutual funds similarly."

Penelitian Ippolito (1993) terhadap 21 mutual funds menyimpulkan bahwa kinerja mutual funds melebihi market return dan ada pula yang di bawah market return, tergantung kualitas informasi yang digunakan dalam mengelola mutual funds. Berikut ini pernyataannya: "thus, we are left with the conclusion that after all factors are considered and after four decades of debate, mutual funds are neither superior nor inferior to the overall market in term of risk-adjusted returns.". Oleh karena itu, dalam penelitian ini menggunakan Model Sharpe dengan alasan lebih cocok digunakan untuk masa ekonomi krisis dikarenakan penggunaan standar deviasi return sebagai tolok ukur risiko. Model Jensen, Model Treynor dan Model Treynor dan Black yang menggunakan beta saham sebagai tolok ukur risiko tidak tepat digunakan pada kondisi ekonomi krisis.

Model Sharpe atau Sharpe Ratio atau Sharpe Index atau Sharpe Performance merupakan istilah yang memiliki arti yang sama. Walaupun penelitian Sharpe meneliti produk reksadana (mutual fund), tetapi temuannya mengenai penilaian kinerja investasi (performance evaluation) dapat dipakai untuk menilai kinerja berbagai jenis investasi. Hasil penelitian Durolles and Christian (2009) menyatakan bahwa Sharpe Performance dapat diterapkan untuk menilai kinerja peringkat perusahaan Hedge Fund.

Tingkat efisiensi pasar berbeda antar negara. Pada pasar yang efisien, perubahan harga saham sangat tipis sehingga tidak mudah meraup keuntungan besar. Akan tetapi pada pasar yang tidak efisien, fluktuasi harga saham sangat besar sehingga mudah mencari keuntungan bagi yang memiliki informasi tentang adanya "saham layak beli" dan "saham layak jual". 
Pada pasar yang efisien, saham kelompok durable goods harganya akan naik tajam pada masa recovery dan akan turun tajam pada masa kontraksi. Perubahan harga sangat sensitif terhadap siklus bisnis. Sebaliknya, saham nondurable goods kurang terpengaruh oleh siklus bisnis. Harga saham kurang sensitif terhadap siklus dan lebih bersifat bertahan atau defensif (Bodie et al., 2008).

Namun demikian, hasil penelitian Monacelli (2008) menyatakan bahwa dalam keadaan kegoncangan kebijakan moneter, durable goods dan nondurable goods bergerak bersama secara positif walaupun durable goods lebih sensitif gerakannya. Selanjutnya, Monacelli (2008) menyatakan; " econometric evidence suggest that in responce to monetary policy shock durable and nondurable spending co-movepositively and durable spending exhibit a much large sensitivity to the shock. A standar two-sector New Keynesian Model with perfect financial market is at odds with these facts".

Adanya kemungkinan penyimpangan dari teori mengenai perilaku nondurable goods telah dinyatakan oleh (Francis 1991) sebagai berikut; "if securities prices reacted to new information inefficiently, securities analysts should be able to make fortune. They could reap large profits by finding undervalued securities, buying them, and holding them in long positions while their prices rise or by finding overvalued securities, selling them short, and holding them in short positions to profit from their falling prices".

Hal ini berarti gejolak harga saham tidak terjadi hanya pada saham durable goods saja, tetapi juga pada saham nondurable goods yang memiliki informasi tidak efisien atau transaksi terjadi di pasar yang tidak efisien. Tingkat gejolak yang tinggi melekat pada produk durable goods daripada nondurable goods. Hal ini ditunjukkan oleh penelitian (Jenn-Hong Tang, 2007) dan (Caplin \& John, 2006). Hasil penelitian Jenn-Hong menyimpulkan bahwa dalam perekonomian Amerika Serikat, sektor durable goods memiliki tingkat volatilitas pertumbuhan lapangan kerja lebih tinggi daripada sektor nondurable goods. Caplin and John menyimpulkan bahwa durable goods merupakan komponen penting dalam siklus bisnis dan model equilibrium atas pasar modal, durable goods menjadi sulit dikarenakan fleksibilitas pembelian individual.

\section{Hipotesis}

Berdasarkan uraian teoritis dan penelitian terdahulu, maka diajukan hipotesis penelitian sebagai berikut:

1. Reward to variability ratio dan excess return atas saham durable goods lebih rendah daripada nondurable goods, untuk masa kontraksi.

2. Reward to variability ratio dan excess return atas saham durable goods lebih tinggi daripada nondurable goods, untuk masa recovery.

3 Reward to variability ratio, excess return, dan risiko atas saham durable goods lebih tinggi pada masa recovery daripada masa kontraksi. 
4. Reward to variability ratio dan excess return atas saham nondurable goods berbeda pada masa recovery daripada masa kontraksi

\section{METODE PENELITIAN}

\section{Model Analisis}

Analisis ini bertujuan untuk menilai kinerja setiap jenis saham. Kinerja positif berarti saham "Layak Beli" dan jika nilai negatif berarti saham "Layak Jual". Penilaian kinerja saham menggunakan Model Sharpe, yaitu reward to variability ratio. Data yang digunakan bersifat data bulanan, terdiri; index harga saham individu, tingkat suku bunga obligasi negara sebagai risk free rate. Reward to Variability Ratio $=[$ average return risk free rate]/standar deviasi.

Rata-rata diambil sesuai jumlah bulan data masing-masing periode kontraksi (11 bulan) dan periode recovery ( 25 bulan). Untuk menentukan kinerja positif dan kinerja negatif maka hasil reward to variability ratio diperingkat dari nilai tertinggi ke nilai terrendah.

\section{Pengambilan Sampel}

Penelitian ini mengambil sampel semua saham yang tercatat di BEI sampai dengan Desember 2007. Jumlah emiten sebanyak 298 perusahaan, terdiri dari 253 saham kelompok durable goods dan 45 saham kelompok nondurable goods.

\section{Pengumpulan Data}

Variabel yang diteliti adalah: index harga saham individu (IHSI) akhir bulanan, tingkat bunga atau kupon Obligasi ritel Indonesia (ORI) sebagai minimum return atau risk free rate, $12 \%$ per tahun atau $1 \%$ per bulan. Biaya transaksi jual beli diperhitungkan sebagai beban bulanan sebesar $0,7 \%$. Deviden tunai diabaikan karena relatif kecil. Data variabel di atas diambil dari bulletin bulanan yang diterbitkan oleh BEI bernama IDX Monthly Statistics

\section{Teknik Analisis}

(1). Menghitung bulanan return bulanan setiap jenis saham, dengan rumus:

$$
\text { (IHSI bln ini } \left.- \text { IHSI }_{\text {bln lalu }}\right) / \text { IHSI }_{\text {bln lalu }} \text { - biaya transaksi }(0,7 \%)
$$

(2). Menghitung excess return bulanan tiap jenis saham; yaitu return bulanan - minimum return (1\%).

(3). Secara periodik menghitung rata-rata excess return tiap jenis saham untuk masa kontraksi 11 bulan dan masa recovery 25 bulan.

(4). Menghitung standar deviasi excess return setiap jenis saham sesuai dengan initial set 11 bulan dan 25 bulan data.

(5). Menghitung reward to variability ratio tiap jenis saham masing-masing untuk masa kontraksi dan masa recovery, yaitu excess return dibagi standar deviasi. 
(6). Memisahkan jenis saham menjadi 2 kelompok, yaitu saham kelompok durable goods dan saham kelompok nondurable goods masing-masing untuk masa kontraksi dan masa recovery.

(7). Melakukan peringkat atas reward to variability ratio, dari nilai RVA terbesar sampai RVA terkecil masing-masing untuk saham kelompok durable goods dan saham kelompok nondurable goods baik untuk masa kontraksi maupun masa recovery.

(8). Menghitung nilai RVA rata-rata atas saham kelompok durable goods dan saham kelompok nondurable goods masing-masing untuk masa kontraksi dan masa recovery.

(9). Menetapkan batas undervalued stocks dan overvalued stocks atas saham kelompok durable goods dan saham kelompok nondurable goods masing-masing untuk masa kontraksi dan masa recovery.

(10). Menganalisis hubungan antara RVA, excess return dan standar deviasi yang melekat pada saham kelompok durable goods dan saham kelompok nondurable goods pada masa kontraksi dan masa recovery.

(11). Melakukan uji beda kinerja saham (RVA);

Pengujian hipotesis menggunakan independent $t$ test dan pair $t$ test dengan tingkat signifikansi $5 \%$.

(12). Pembahasan.

Membandingkan kajian antara teori dan hasil penelitian.

\section{HASIL ANALISIS DAN PEMBAHASAN}

Masa kontraksi, yaitu penurunan IHSG mulai terjadi bulan Januari 2008 dan mencapai titik terendah IHSG pada bulan Nopember 2008. IHSG turun dari posisi 2.746 (Desember. 2007, bulan ke 1) menjadi posisi 2.627 (Januari 2008, bulan ke 2) dan berlanjut terus setiap bulan sampai pada posisi 1.242 (Nopember 2008, bulan ke 12). Pada masa kontraksi IHSG telah turun sebanyak 55\% sepanjang 11 bulan (sebagai initial set).

Masa recovery, yaitu pemulihan kenaikan IHSG (Desember 2008, bulan ke 13) mulai terjadi dan terus berlangsung setiap bulan dan sampai ke posisi bulan Desember 2010 sebagai batas terakhir periode penelitian ini. IHSG bertengger pada posisi 3.704 (Desember 2010, bulan ke 37).

Pada masa recovery IHSG naik lagi 200\% dari index terendah (Nopember 2008) atau naik 35\% dari index sebelum krisis terjadi (Desember 2007=index 2.746). Masa recovery $=25$ bulan sebagai initial set. Berikut Tabel 1 IHSG BEI Bulanan yang menggambarkan fluktuasi harga saham gabungan sebagai dampak krisis finansial global tahun 2008. 
Tabel 1

IHSG BEI Bulanan

\begin{tabular}{llll}
\hline \hline & $\mathbf{2 0 0 8}$ & $\mathbf{2 0 0 9}$ & $\mathbf{2 0 1 0}$ \\
\hline Des.2007 & $\mathbf{2 , 7 4 6}$ & & \\
Jan. & 2,627 & 1,333 & 2,611 \\
Feb & 2,722 & 1,285 & 2,549 \\
Mrt & 2,447 & 1,434 & 2,777 \\
Apr & 2,305 & 1,723 & 2,971 \\
Mei & 2,444 & 1,917 & 2,797 \\
Juni & 2,349 & 2,027 & 2,914 \\
Juli & 2,305 & 2,323 & 3,069 \\
Aug & 2,166 & 2,342 & 3,082 \\
Sep & 1,833 & 2,468 & 3,501 \\
Okt & 1,257 & 2,368 & 3,635 \\
Nop & $\mathbf{1 , 2 4 2}$ & 2,416 & 3,531 \\
Des & 1,355 & 2,534 & 3,704 \\
\hline
\end{tabular}

IHSG BEI pada Tabel 1dapat digambarkan seperti pada Gambar 1 berikut,

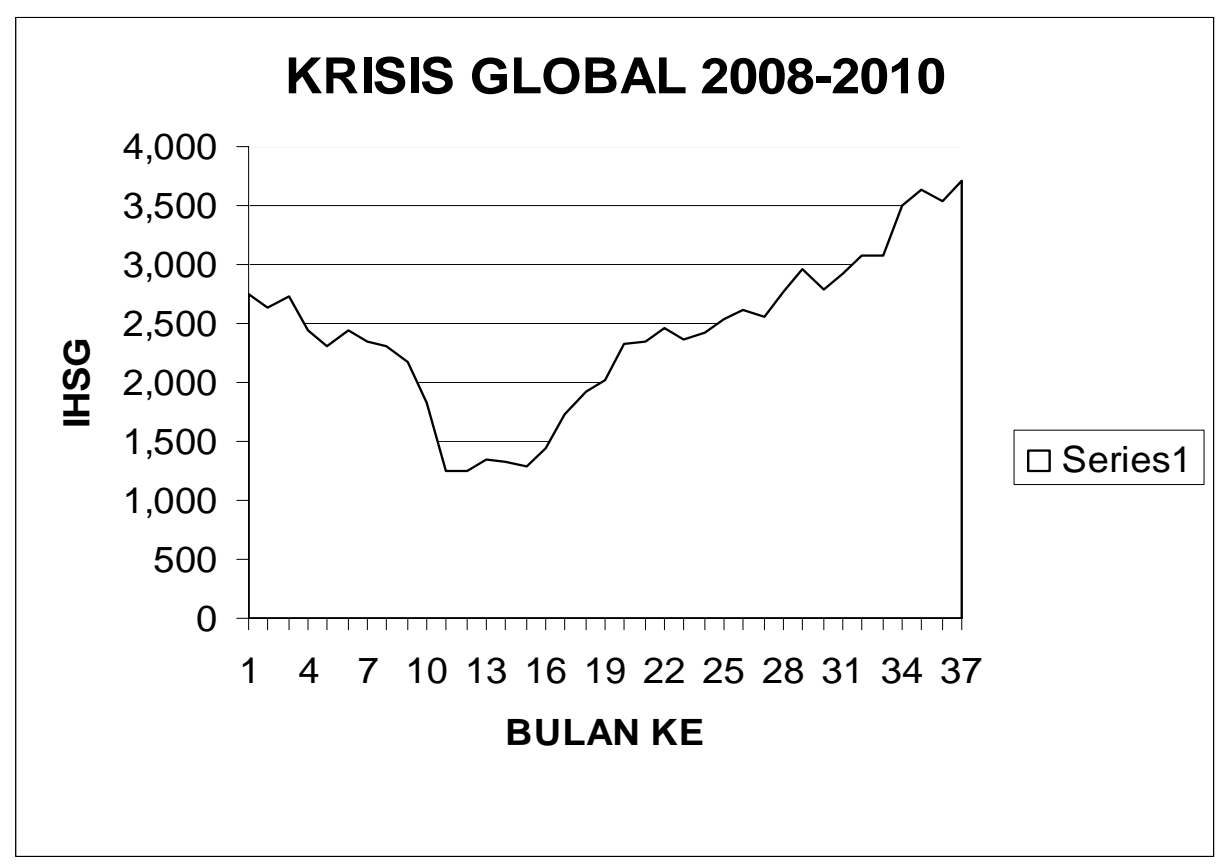

Gambar 1

Fluktuasi IHSG Bursa Efek Indonesia Desember 2007 s/d Desember 2010

Kinerja Saham Durable Goods Dan Nondurable Goods (Mohamad Samsul) 
Pada Gambar 1 dapat diketahui bahwa indeks bulan ke 1 sama dengan IHSG Desember 2007 (posisi pada 2.746). IHSG mulai turun pada bulan ke 2 (Januari 2008) terus menerus setiap bulan sampai mencapai titik terendah pada posisi 1.242 pada akhir Bulan Nopember 2008 (bulan ke 12). Kemudian berbalik arah mulai Bulan Desember 2008 (bulan ke 13) setiap bulan terus menerus selama 25 bulan sampai Desember 2010 (bulan ke 37).

Dampak krisis finansial global terhadap suatu kelompok saham pada tahapan siklus bisnis, siklus kontraksi (penurunan ekonomi) dan siklus recovery (pemulihan ekonomi) dapat dilihat pada tabel 2 .

Tabel 2

Saham Kelompok Durable Goods Masa Kontraksi

\begin{tabular}{llllll}
\hline \hline & Kinerja & Excess Return & Stdev. & Jumlah & Jumlah \\
\hline & RVA & $\mathrm{R} i$ & $\sigma$ & Emiten & $\%$ \\
Overvalued stocks & -0.501 & -0.07 & 0.164 & 219 & 87 \\
Undervalued stocks & 0.194 & 0.053 & 0.276 & 34 & 13 \\
& & & & 253 & 100 \\
\hline
\end{tabular}

Pada masa kontraksi, yang berjalan selama 11 bulan dari Januari 2008 sampai dengan Nopember 2008, jumlah saham yang mengalami penurunan harga sebanyak 219 jenis atau $87 \%$ dari total 253 jenis. Tingkat penurunan harga saham rata-rata mencapai $7 \%$ per bulan. Tingkat risiko $16,4 \%$ atau 2,5 kali excess return.

Hal ini berarti dalam masa kontraksi banyak investor mengalami kerugian. Namun, ada sebagian kecil investor (13\%) yang memperoleh keuntungan. Sebagian kecil pemegang saham berani membeli dengan harga lebih tinggi untuk memperbaiki kualitas portfolionya. Dampak krisis finansial global terhadap saham kelompok durable goods di atas tampak bersifat normal.

Tabel 3

Saham Kelompok Nondurable Goods Masa Kontraksi

\begin{tabular}{llllll}
\hline \hline & Kinerja & Excess Return & Stdev. & Jumlah & Jumlah \\
\hline & RVA & $\mathrm{R} i$ & $\sigma$ & Emiten & $\%$ \\
Overvalued stocks & -0.58 & -0.074 & 0.136 & 36 & 80 \\
Undervalued stocks & 0.149 & 0.04 & 0.231 & 9 & 20 \\
& & & & 45 & 100 \\
\hline
\end{tabular}


Sementara itu, Tabel 3 menunjukkan bahwa pada masa kontraksi, saham kelompok nondurable goods yang mengalami penurunan harga mencapai 36 jenis atau $80 \%$ dari total 45 jenis pada tingkat penurunan harga $7,4 \%$ per bulan sebagai hal yang tidak wajar, jika dibandingkan dengan penurunan harga saham durable goods 7\% (lihat Tabel 2). Saham kelompok nondurable goods secara teoritis bersifat tidak sensitif terhadap perubahan siklus bisnis. Hal ini sebagai indikator bahwa pasar modal di Indonesia masih belum termasuk pasar yang efisien.

Tabel 4

Saham Kelompok Durable Goods

Masa Recovery

\begin{tabular}{llllll}
\hline \hline & Kinerja & Excess Return & Stdev. & Jumlah & Jumlah \\
\hline & RVA & $\mathrm{R} i$ & $\sigma$ & Emiten & $\%$ \\
Overvalued stocks & -0.187 & -0.02 & 0.123 & 64 & 25 \\
Undervalued stocks & 0.218 & 0.045 & 0.211 & 189 & 75 \\
& & & & 253 & 100 \\
\hline
\end{tabular}

Tabel 4 menyatakan bahwa pada masa recovery, yaitu masa pemulihan ekonomi yang berlangsung selama 25 bulan sejak Desember 2008 sampai dengan Desember 2010, sebanyak 189 saham atau $75 \%$ dari total 253 jenis mengalami kenaikan harga saham. Kenaikan harga saham mencapai 4,5\% rata-rata per bulan dengan penyebaran perbedaan $21 \%$. Pada masa recovery sebagian besar saham mengalami kenaikan harga, tetapi selalu ada sebagian kecil yang mengalami penurunan harga.

Tabel 5

Saham Kelompok Nondurable Goods Masa Recovery

\begin{tabular}{llllll}
\hline \hline & Kinerja & Excess Return & Stdev. & Jumlah & Jumlah \\
\hline & RVA & Ri & $\sigma$ & Emiten & $\%$ \\
Overvalued stocks & -0.163 & -0.017 & 0.143 & 9 & 20 \\
Undervalued stocks & 0.261 & 0.04 & 0.159 & 36 & 80 \\
& & & & 45 & 100 \\
\hline
\end{tabular}

Pada masa recovery, ternyata sebagian besar saham nondurable goods yang mengalami kenaikan tajam mencapai $80 \%$ dari total 45 jenis saham. Kenaikan tajam dimaksud sebesar $4 \%$ rata-rata per bulan. Kenaikan 4\% tersebut tidak jauh berbeda dengan kenaikan saham kelompok durable goods yang mencapai 4,5\% rata-rata per bulan untuk masa recovery yang sama (lihat Tabel 4). Gejolak kenaikan harga saham nondurable goods sebesar 16\% atau lebih rendah 5\% daripada gejolak harga saham durable goods 
pada masa recovery (lihat Tabel 4). Pada masa recovery sebagian besar saham mengalami kenaikan harga, tetapi selalu ada sebagian kecil yang mengalami penurunan harga.

\section{Uji Hipotesis}

Hasil pengujian hipotesis saham kelompok durable goods dan kelompok nondurable goods dapat dilihat pada Tabel 6.

Tabel 6

Hasil Uji Hipotesis 1 Masa Kontraksi

\begin{tabular}{lllll}
\hline \hline & & Excess & & \\
Keterangan & Kinerja & Return & Stdev. & Jumlah \\
\hline & RVA & Ri & $\sigma i$ & Emiten \\
Saham Durable goods & -0.407 & -0.054 & 0.189 & 253 \\
Saham nondurable goods & -0.434 & -0.051 & 0.156 & 45 \\
Beda & 0.027 & -0.003 & 0.033 & \\
p-value & 0.359 & 0.000 & 0.910 & \\
\hline
\end{tabular}

Berdasarkan Tabel 6 dapat diketahui bahwa kinerja saham (reward to variability ratio) kelompok durable goods lebih tinggi 2,7\% daripada nondurable goods, tetapi perbedaan itu tidak signifikan (hipotesis 1 tidak terbukti). Kinerja bernilai negatif berarti saham bersangkutan "layak dijual". Nilai kinerja saham kelompok durable goods lebih tinggi $2,7 \%$ (turun lebih rendah) daripada saham kelompok nondurable goods merupakan suatu penyimpangan dari teori. Hal ini dikarenakan pada masa kontraksi terjadi penurunan harga saham yang relatif sama antara kelompok durable goods dan kelompok nondurable goods, yaitu 5,4\% dan 5,1\%. Padahal secara teoritis, saham kelompok nondurable goods itu tidak terlalu sensitif terhadap siklus bisnis.

Tabel 7

Hasil Uji Hipotesis 2 - Masa Recovery

\begin{tabular}{lllll}
\hline \hline & Kinerja & Excess return & Stdev. & Jumlah \\
\hline & RVA & $R i$ & $\sigma i$ & Emiten \\
Saham Durable goods & 0.116 & 0.029 & 0.179 & 253 \\
Saham nondurable goods & 0.176 & 0.028 & 0.155 & 45 \\
Beda & -0.060 & 0.001 & 0.024 & \\
p-value & 0.997 & & & \\
\hline
\end{tabular}

Pada masa recovery, kinerja saham (reward to variability ratio) kelompok durable goods lebih rendah 6,0\% daripada nondurable goods dan perbedaan itu tidak signifikan. Dengan demikian hipotesis 2 tidak terbukti. Kinerja bernilai positif berarti saham bersangkutan 
"layak dibeli". Namun demikian, kinerja saham nondurable goods lebih tinggi dari pada saham kelompok durable goods pada masa recovery merupakan penyimpangan dari teori. Secara teoritis saham kelompok nondurable goods tidak terlalu sensitif terhadap perubahan siklus bisnis. Akan tetapi, kenaikan harga saham nondurable goods secara tajam pada masa recovery dapat dikarenakan penurunan tajam pada saat masa kontraksi sebelumnya. Hal ini merupakan penyesuaian harga segera terjadi yang berbalik arah pada saat masa recovery.

Tabel 8

Hasil Uji Hipotesis 3 - Saham Durable Goods

\begin{tabular}{lllll}
\hline \hline & Kinerja & Excess return & Stdev. & Jumlah \\
\hline & RVA & $\mathrm{R} i$ & $\sigma$ & Emiten \\
Masa Recovery & 0.116 & 0.029 & 0.189 & 253 \\
Masa Kontraksi & -0.407 & -0.054 & 0.179 & 253 \\
Beda & 0.523 & 0.083 & 0.010 & \\
p-value & 0.000 & & & \\
\hline
\end{tabular}

Kinerja saham (RVA) durable goods lebih tinggi pada masa recovery dari pada masa kontraksi sangat meyakinkan. Hasil uji hipotesis menunjukkan saham durable goods memiliki RVA jauh lebih tinggi daripada nondurable dengan perbedaan yang signifikan. Hal ini berarti hipotesis 3 terbukti. Pada masa recovery, kinerja saham kelompok durable goods bernilai positif berarti saham kelompok ini layak dibeli, sedangkan pada masa kontraksi bernilai negatif yang berarti layak dijual. Dari total saham kelompok durable goods berjumlah 253 jenis, yang layak dibeli pada masa recovery sebanyak 189 jenis atau $75 \%$ (lihat Tabel 4) dan yang layak dijual pada masa kontraksi sebanyak 219 jenis atau $87 \%$ (lihat Tabel 2).

Tabel 9

Hasil Uji Hipotesis 4 - Saham Nondurable Goods

\begin{tabular}{lllll}
\hline \hline & Kinerja & Excess return & Stdev. & Jumlah \\
\hline & RVA & $\mathrm{R} i$ & $\sigma$ & Emiten \\
Masa Recovery & 0.176 & 0.028 & 0.156 & 45 \\
Masa Kontraksi & -0.435 & -0.051 & 0.155 & 45 \\
Beda & 0.611 & 0.079 & 0.001 & \\
$p$-value & 0.000 & & & \\
\hline
\end{tabular}

Kinerja saham kelompok nondurable goods berbeda signifikan antara masa recovery dan masa kontraksi. Berdasarkan hal tersebut, maka hipotesis 4 terbukti. Namun demikian, hasil penelitian ini menunjukkan adanya penyimpangan dari teori mengenai kinerja 
saham nondurable goods. Secara teori harga saham nondurable goods tidak terlalu sensitif terhadap siklus bisnis. Hal ini berarti ada indikator bahwa pasar modal di Indonesia tidak termasuk sebagai pasar yang efisien.

\section{Pembahasan}

Krisis finansial global tahun 2008 yang berawal dari Amerika Serikat telah berdampak negatif terhadap perekonomian di banyak negara. Dampak negatif terhadap sektor ekonomi riil tidak sama bagi setiap negara tergantung pada tinggi rendahnya hubungan dagang internasional terutama dengan Amerika Serikat, namun untuk sektor finansial dampak negatif tersebut tampak hampir merata. Hal ini menunjukkan bahwa perekonomian dunia sudah dalam sistem ekonomi global. Gejolak ekonomi yang terjadi di suatu negara yang pegang dominasi variabel ekonomi dunia akan berpengaruh luas ke negara lainnya.

Sebagai contoh, krisis finansial global tahun 2008 telah berpengaruh pada sektor ekonomi riil Indonesia sekitar 15\%, tetapi di sektor pasar modal Index Harga Saham Gabungan (IHSG) terjadi penurunan sekitar 55\% selama 11 bulan masa kontraksi (Januari s/d Nopember 2008). IHSG Bursa Efek Indonesia segera pulih kembali (recovery) sejak Desember 2008 sampai dengan Desember 2010 IHSG kembali ke angka seperti sebelum krisis bahkan berlanjut terus menerus setiap bulan sampai akhir Desember 2010 sebagai batas penelitian.

Hasil penelitian mengenai dampak krisis terhadap kinerja saham menunjukkan bahwa: (1) Kinerja saham kelompok durable goods berbeda tidak signifikan dengan kinerja saham kelompok nondurable goods baik untuk masa kontraksi maupun masa recovery. Pada masa kontraksi, sebagian besar saham kelompok durable goods dan sebagian besar saham kelompok nondurable goods "layak dijual" dan sebagian kecil termasuk "layak dibeli". Pada masa recovery, sebagian besar saham kelompok durable goods dan sebagian besar saham kelompok nondurable goods "layak dibeli" dan sebagian kecil termasuk "layak dijual".

Hasil penelitian ini menunjukkan adanya penyimpangan dari teori mengenai kinerja saham nondurable goods. Seharusnya, saham kelompok nondurabale goods ini tidak banyak terpengaruh oleh siklus bisnis, karena di pasar modal yang efisien harga saham nondurable goods itu tidak terlalu sensitif terhadap siklus bisnis. Namun kenyataannya, saham nondurable goods sangat terpengaruh pada masa kontraksi dan masa recovery di Indonesia. Hal ini berarti pasar modal Indonesia tidak termasuk pasar yang efisien. Hasil penelitian ini sesuai dengan hasil penelitian terdahulu yang dilakukan oleh Monacelli, (2008) di pasar finansial sempurna dan hal ini dianggap sebagai keanehan nyata. 
(2) Kinerja saham kelompok durable goods berbeda signifikan antara masa recovery dan masa kontraksi. Demikian juga kinerja saham nondurable goods berbeda signifikan antara masa recovery dan kontraksi. Pada masa kontraksi, kebanyakan saham durable goods mengalami penurunan harga yang tajam merupakan suatu kondisi normal. Akan tetapi harga yang tajam dari saham nondurable goods adalah suatu yang tidak normal. Dengan kata lain kasus saham nondurable goods yang mengalami kenaikan dan penurunan harga secara tajam pada masa recovery dan masa kontraksi, sama seperti yang dialami saham durable goods. Hal ini dapat menunjukkan bahwa pasar modal di Indonesia tidak efisien.

(3) Suatu pasar yang tidak efisien dapat menguntungkan bagi investor yang mempunyai informasi tentang saham yang "layal beli" ataupun yang "layak jual". Dengan demikian untuk investor di Pasar Modal Indonesia, disarankan (a) "jangan menahan" atau "jangan membeli" saham kelompok nondurable goods pada saat ekonomi akan memasuki siklus kontraksi dan lebih baik "menjual" saham yang dimiliki; (b) membeli saham nondurable goods pada saat setelah 3 bulan terjadi kenaikan harga saham terus menerus.

\section{SIMPULAN, SARAN, DAN KETERBATASAN}

\section{Simpulan}

Setiap gejolak ekonomi dari negara yang mendominasi faktor ekonomi internasional akan berpengaruh terhadap negara lainnya walaupun berbeda skala dampaknya. Dampak positif ataupun negatif harus diantisipasi oleh investor dan mengambil keputusan keluar atau masuk dari dan ke pasar modal. Untuk mengurangi kerugian investasi saham, maka jika harga saham di pasar terus menurun berturut-turut selama 3 bulan, itu sebagai tanda awal adanya resesi. Investor sebaiknya memperhatikan perkembangan ekonomi makro nasional atau internasional untuk meyakinkan adanya masa resesi. Investor akan kembali lagi berinvestasi saham setelah ada informasi harga saham mulai naik terus-menerus selama 3 bulan. Pada prinsipnya, investor keluar dari pasar pada awal-awal bulan penurunan harga saham dan masuk kembali pada awal-awal bulan kenaikan harga saham.

Hasil penelitian ini menunjukkan bahwa:

(1) Kinerja saham antara kelompok durable goods dan non durabale goods berbeda tidak signifikan pada masa kontraksi.

(2) Kinerja saham antara kelompok durable goods dan non durabale goods berbeda tidak signifikan pada masa recovery.

(3) Kinerja saham kelompok durable goods berbeda signifikan antara masa recovery dan masa kontraksi.

(4) Kinerja saham kelompok nondurable goods berbeda signifikan antara masa recovery dan masa kontraksi. 
Hasil penelitian ini menunjukkan bahwa perilaku harga nondurable goods relatif sama dengan perilaku durable goods dalam kondisi kegoncangan pasar finansial. Hasil penelitian ini sama dengan hasil penelitian sebelumnya (Monacelli, 2008).

Hasil penelitian ini dapat menujukkan bahwa pasar modal di Indonesia tidak termasuk pasar yang efisien. Namun demikian, adanya pasar yang tidak efisien memberi peluang untuk meraup keuntungan bagi investor yang memiliki informasi tentang saham yang termasuk kelompok "layak beli" atau undervalued stock dan "layak jual" atau overvalued stocks terutama pada saat krisis.

\section{Saran}

Di Negara yang pasar modalnya sudah efisien, harga saham nondurable goods tidak terpengaruh banyak dengan siklus bisnis sehingga investor lebih senang menahan portofolio saham nondurable goods. Namun demikian, jika terjadi kegoncangan hebat di pasar finansial, hasil penelitian terdahulu dan hasil penelitian ini menunjukkan bahwa produk durable goods dan nondurable goods bergerak bersama secara positif.

Berdasarkan hasil penelitian ini tentang kinerja saham kelompok nondurable goods, yaitu adanya gejolak harga saham yang tajam pada masa kontraksi dan masa recovery pada pasar modal di Indonesia, maka investor sebaiknya melakukan tindakan sebagai berikut:

A. Tindakan dalam masa kontraksi;

a. Menjual saham nondurable goods pada awal-awal penurunan harga saham, jika memiliki portofolio.

b. Jangan membeli saham selama masa kontraksi berlangsung.

c. Menekan portofolio saham sekecil mungkin selama masa kontraksi.

d. Mewaspadai terus-menerus pergerakan harga saham menjelang perubahan siklus berikutnya.

B. Tindakan dalam masa recovery;

a. Membeli saham nondurable goods pada awal-awal kenaikan harga saham, untuk membentuk portofolio baru.

b. Pembelian dilakukan bertahap selama masa recovery.

c. Mencapai proporsi portofolio sesuai yang ditetapkan.

d. Mengawasi terus menerus pergerakan harga saham menjelang perubahan siklus berikutnya.

\section{Keterbatasan}

Penelitian ini memiliki keterbatasan dalam hal;

1. Tidak membahas dampak krisis finansial global terhadap perekonomian negaranegara di luar Indonesia.

2. Penelitian ini hanya membahas dampak terhadap sektor ekonomi riil Indonesia secara garis besar. Penelitian ditekankan pada sektor pasar modal di Indonesia, khususnya terhadap saham dari industri durable goods dan industri non durable goods. 
3. Faktor risk free rate yang digunakan dipilih tingkat kupon obligasi ritel Indonesia (ORI) yang pernah diterbitkan sebesar $12 \%$ per tahun atau $1 \%$ per bulan. Biaya transaksi jual dan beli saham yang dibayar investor kepada broker dianggap rata-rata untuk transaksi jual $0,4 \%$ dan transaksi beli $0,3 \%$ atau total $0,7 \%$ dari harga setiap akhir bulan.

\section{DAFTAR PUSTAKA}

Bodie, Zvi., Alex Kane, and Alan J. Marcus. 2002. Investments. Fifth Edition. International Edition. McGraw-Hill Company, Inc. New York.

---------. 2008. Investments. Seventh Edition. International Edition: McGraw-Hill Company, Inc. New York.

Bursa Efek Indonesia, IDX Monthly Statistics. Januari s/d Desember tahun 2008 sampai Desember tahun 2010.

Caplin Andrew, John Leahy. 2006. Equilibrium in a durable Goods Market with Lumpy Adjustment. Journal of Economics Theory. 128(1): 187-213

Durolles Serge, Christian Courieroux. 2009. "Conditioannally Fitted Sharpe Performance With an Application to Hedge Fund Rating". Journal of Banking \& Finance. Edisi September (2).

Francis. 1991. Investment: Analysis and Management. $5^{\text {th }}$ edition.

Ippolito, Richard A. 1993. "On Studies of Mutual Funds Performance, 1962-1991," Financial Analysts Journal, January-February: 42-50.

Jensen, Michael C. 1968. " The Performance of Mutual Funds in the Period 1945-1964," Journal of Finance, May: 389-416.

Jenn-Hong Tang. 2007. "Gross Job Flows and Technology Shocks in nondurable Goods and Durable Goods Sectors". Journal of Macroeconomics. March.

Markowitz, Harry. 1952. "Portfolio Selection”, Journal of Finance, 7(1): 77-91

McDonald, John G. 1974. " Objectives and Performance of Mutual Funds, 1960-1969," Journal of Financial and Quantitative Analysis. June: 311-333. 
Modigliani Leah, and Franco Modigliani. 1997. "Risk Adjusted Performance”. Journal of Portfolio Management. Winter: 45-54

Monacelli, Tommaco. 2008. "New Keynesion Models, durable goods and collateral constraints". Journal of Monetary Economics. 14 October.

Sharpe William F. 1966. "Mutual Funds Performance," Journal of Business, 39, January: $119-138$

Treynor, Jack L. 1965. "How to Rate Management Investment Funds," Harvard Business Review, 43 January-February: 63-75. 